\title{
Diel and seasonal patterns of Nephrops norvegicus (Decapoda: Nephropidae) catchability in the western Mediterranean
}

\author{
Jacopo Aguzzi*, Francesc Sardà, Pere Abelló, Joan B. Company, Guiomar Rotllant \\ Institut de Ciències del Mar (CSIC), Passeig Marítim de la Barceloneta 37-49, 08003 Barcelona, Spain
}

\begin{abstract}
Catchability patterns of western Mediterranean Nephrops norvegicus were studied in relation to depth and season by sampling animals during 4 continuous $24 \mathrm{~h}$ cycles of trawl hauls at 100 to $110 \mathrm{~m}$ and 400 to $430 \mathrm{~m}$ in October (near the autumn equinox) and June (near the summer solstice). Bottom light intensity was recorded between consecutive catches. Catch data were transformed into density estimates of animals emerging from their burrows. Results revealed a marked emergence rhythmicity: nocturnal with crepuscular peaks on the continental shelf, and diurnal on the continental slope. On the slope, peaks of catch occurred in phase with light intensity, whereas this did not happen on the shelf. In particular, both benthic environments presented diel fluctuations in light intensity that differed within several orders of magnitude. These data indicate a differential physiological adaptation of $N$. norvegicus eyes to local photic conditions, implying a revision of the optimum light intensity concept, already proposed in the literature. Emergence patterns were almost identical for males, females and berried females, and these were not size-dependent.
\end{abstract}

KEY WORDS: Nephrops norvegicus · Mediterranean - Catchability · Rhythms · Continental shelf · Continental slope $\cdot$ Light intensity

Resale or republication not permitted without written consent of the publisher

\section{INTRODUCTION}

The decapod crustacean Nephrops norvegicus (L.) shows a high variability in catch over the $24 \mathrm{~h}$ cycle, as an indication of a fluctuation in the numbers of individuals undertaking emergence from their burrows (Chapman et al. 1972, 1975). In fact, animals inside or at the entrance of their burrows easily avoid capture by retracting themselves when trawl nets approach (Chapman \& Rice 1971, Rice \& Chapman 1971, Farmer 1974b, Main \& Sangster 1985).

The relation between rhythmicity of catch and depth of animal distribution has been well documented since the early 1960s (Andersen 1962, O'Riordan 1964, Simpson 1965). Field surveys indicated a timing shift in peaks of catches with depth, suggesting the presence of a bathymetric trend in species emergence behaviour. In the NE Atlantic shallow continental shelf $(<30 \mathrm{~m})$, peaks of catch were recorded during the night
(Andersen 1962, Farmer 1975, Moller \& Naylor 1980). In the same area, on the lower continental shelf (60 to $200 \mathrm{~m}$ ), high catches were observed at around dawn and dusk (Chapman et al. 1972, 1975, Farmer 1974a, Chapman \& Howard 1979, Oakley 1979). For depths greater than $200 \mathrm{~m}$, Chapman et al. $(1972,1975)$ hypothesised a midday timing of emergence behaviour. The only available data on emergence rhythmicity in Mediterranean populations were those referring to Adriatic Sea continental shelf areas, where the same pattern of continental shelf populations in the Atlantic was recorded (Jukic 1971, Froglia 1972).

Chapman et al. $(1972,1975)$ proposed a regulatory mechanism named as the 'optimum light intensity con-

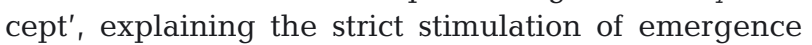
behaviour for light intensity values comprised between 1 and $10^{-5} \mathrm{~lx}$. Following this idea, the same optimum environmental illumination should be obtained at different hours of the day at different depths, depending 
on the position of the sun, and thus, on the light penetration power. Along with these considerations, a cross effect of season could be expected, by simply assuming that the timing and duration of the optimum illumination level depends upon seasonal photoperiod length duration.

In the western Mediterranean, Nephrops norvegicus populations are mainly located in deeper waters on the upper and middle continental slope (300 to $600 \mathrm{~m}$ ) (Abelló et al. 1988, 2002a,b, Cartes \& Sardà 1993, Maynou \& Sardà 1997, Maynou et al. 1998), where direct light stimuli are much more restricted. In order to examine the modulation of the $N$. norvegicus catchability patterns with light intensity variations at different depths and under different photoperiod length regimes, $24 \mathrm{~h}$ cycles of consecutive trawl hauls were performed on the continental shelf and slope off the Catalan coast in autumn and summer. The catch rhythmicity was analysed taking into account the size and sex structure of samples.

\section{MATERIALS AND METHODS}

Sampling. Two research cruises were carried out in 2 different seasons to account for photoperiod length differences: October (from 28 September 1999 to 8 October 1999) and June (22 June 2000 to 03 July 2000), near the autumn equinox (with approximately $12 \mathrm{~h}$ day and $12 \mathrm{~h}$ night) and the summer solstice (with daylight hours far exceeding night-time hours at, approximately, latitude $41^{\circ} \mathrm{N}$ ), respectively. Two neighbouring populations were investigated, one on the continental shelf (100 to $110 \mathrm{~m}$ ) off the Ebro delta (lati-

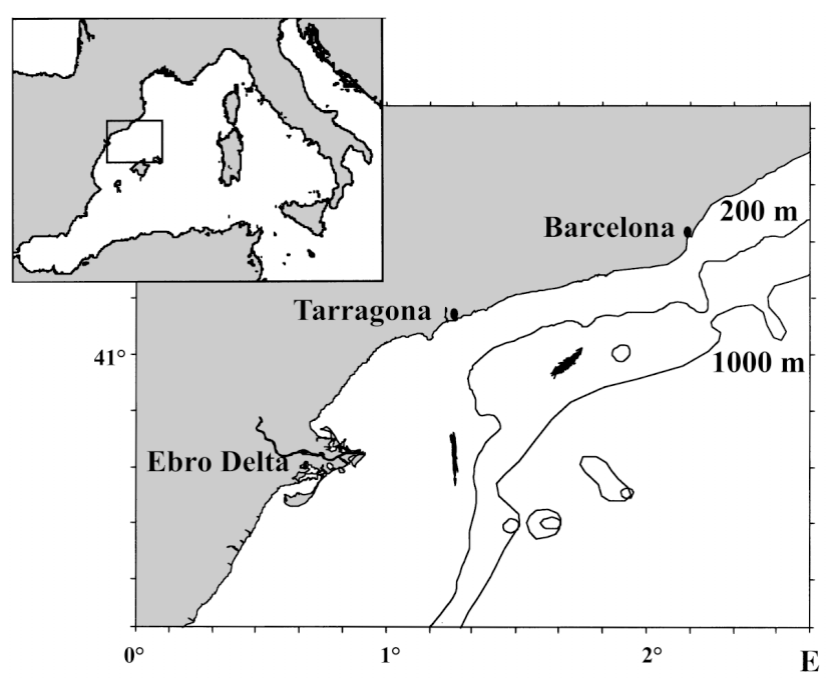

Fig. 1. Sampling areas off the Catalan coast (western Mediterranean). Black spots: transect haul areas tude and longitude ranges: $40^{\circ} 39^{\prime} \mathrm{N}, 1^{\circ} 13^{\prime} \mathrm{E} ; 40^{\circ} 38^{\prime} \mathrm{N}$, $\left.1^{\circ} 11^{\prime} \mathrm{E}\right)$, and the other located on the slope (400 to $430 \mathrm{~m}$ ) off Tarragona $\left(41^{\circ} 1^{\prime} \mathrm{N}, 1^{\circ} 37^{\prime} \mathrm{E} ; 40^{\circ} 55^{\prime} \mathrm{N}\right.$, $1^{\circ} 31^{\prime} \mathrm{E}$ ) (Fig. 1). High demographic areas were chosen according to Maynou et al. (1998). All field surveys were carried out onboard RV 'García del Cid' (38 m length; $1200 \mathrm{HP}$ ) equipped with otter trawl nets of $27.5 \mathrm{~mm}$ headrope size (Otter Trawl Maireta System; Sardà et al. 1998).

In every bathymetric station, a $24 \mathrm{~h}$ cycle of trawl hauls was continuously carried out during $4 \mathrm{~d}$ along the same transect. In October, 32 hauls were made on the shelf and 34 on the slope. In June, 32 hauls were performed on both the shelf and the slope. The duration of hauls was $30 \mathrm{~min}$ at $400 \mathrm{~m}$, and $90 \mathrm{~min}$ at $100 \mathrm{~m}$ to account for the lower densities of the species on the continental shelf (Abelló et al. 1988, 2002a,b, Cartes \& Sardà 1993, Maynou \& Sardà 1997, Maynou et al. 1998). A GPS system recorded the ship velocity and the initial and final position (latitude and longitude) for all hauls, while the echosounder provided depth measures. Scanmar remote sensors were connected to the net mouth to record wings opening $(\mathrm{m})$ and depth $(\mathrm{m})$, telemetrically storing such data per minute on an onboard computer. Initial and final trawl times were reported considering the exact moment of the net landing and rising from the bottom surface, according to Scanmar remote sensing information.

Light intensity was sampled between consecutive hauls. The photometer employed (LI-193SA Spherical Quantum Sensor) measured the light intensity as photon fluency rate $\left(P F R, \mu E_{i} m^{-2} s^{-1}\right)$ in a wavelength range comprised between 400 and $700 \mathrm{~nm}$ (PAR: photosynthetically active radiation). This wavelength range does not account for fluctuations in monochromatic light intensity, although it is narrower compared to the one used to obtain lux measures (380 to $770 \mathrm{~nm}$ ). The illumination on the slope was outside the sensibility range of the photometer, and consequently, light was directly sampled at 100 and $300 \mathrm{~m}$. Next, illumination at $400 \mathrm{~m}$ was calculated by multiplying measures obtained at $300 \mathrm{~m}$ by an attenuation coefficient $(\mathrm{K})$ that quantifies the effect of the water column on light absorption and scattering (see Gaten et al. 1990 for the details of the procedure employed).

For each haul, all Nephrops norvegicus were sorted, counted, sexed and measured with a calliper for their carapace length $(\mathrm{CL} \pm 0.1 \mathrm{~mm}$ precision). The proportion of males, females and berried females in the catches was also calculated.

Catchability rhythms. The catchability rhythms were assessed by estimating the animals densities over the $24 \mathrm{~h}$ cycles. Catches can be considered as directly proportional to surface density estimates of those animals undertaking emergence outside their burrows 
(Chapman \& Howard 1979, Main \& Sangster 1985, Newland et al. 1992). Consequently, the terms 'catch' and 'density' are considered as synonymous in the present investigation. A density value per haul was obtained by dividing the number of sampled animals by the swept area $\left(\mathrm{km}^{2}\right)$, as estimated by Scanmar and GPS measures (Sparre et al. 1989).

To assess a modulation of emergence upon light intensity cycles, temporal series of density estimates and illumination measures were plotted together, for both the shelf and slope environments in October and June. The GMT initial time of each haul was considered. The exact sunset and sunrise timings at the latitude of the study area were also taken into account (17:39 and 05:44 h on 28 October; 19:27 and 04:19 h on 22 June).

The phase of emergence patterns and its agreement with light cycles was obtained by a $24 \mathrm{~h}$ form-estimate analysis of the temporal series of density estimates and illumination (PFR) values. A standard period of $24 \mathrm{~h}$ was subdivided into $2 \mathrm{~h}$ time intervals. All density and PFR estimates computed from hauls whose timing took place within each $2 \mathrm{~h}$ time interval were averaged to obtain the $24 \mathrm{~h}$ form estimate. Table 1 shows the number of samples used to estimate the mean density within each $2 \mathrm{~h}$ time interval. For those $2 \mathrm{~h}$ time intervals where no hauls were performed (for technical reasons) during the $4 \mathrm{~d}$ of fishing activity, an average density from adjacent time interval values was estimated.

The determination of the exact periodicity in the recorded patterns of catches was screened between 4 and $30 \mathrm{~h}$ with a periodogram analysis program (PERIO 7.0; Aagaard et al. 1995), based on the procedure of Williams \& Naylor (1978). Periodogram analysis is an extension of the Buys-Ballot Table, requiring time series of data drawn at a constant time interval, a condition difficult to accomplish in field studies. Temporal gaps in data were therefore replaced by values obtained from the $24 \mathrm{~h}$ form-estimate at the corresponding time interval. Peaks indicating the inherent significant periodicity correspond to those crossing the $95 \%$ upper-limit confidence interval. Obviously, for those outputs showing 2 significant peaks, only the first one was taken into account, the second being considered a multiple of the first.

To assess whether a differential timing in the emergence rhythmicity of both sexes was taking place, density estimates were computed separately for males and females. The influence of the spawning condition on the emergence rhythmicity was assessed by calculating the density of berried females on the slope in October, since this is the season coinciding with egg incubation period in the study area (Sardà 1995). Samples from the shelf population were not considered for this analysis, given the much lower densities of berried females sampled.
To assess whether size-related differences were taking place in emergence rhythmicity, all sampled individuals were pooled into 3 size classes (Sardà 1991): juveniles (CL < $25 \mathrm{~mm})$, medium-sized adults $(25<\mathrm{CL}$ $<35 \mathrm{~mm}$ ), and large adults (CL > $35 \mathrm{~mm}$ ). For each haul, a density estimate was computed separately for the 3 size classes. Next, a $24 \mathrm{~h}$ form-estimate analysis was carried out on the temporal series of density estimates of each size class, as previously described.

Size frequency distributions by sex were constructed for each survey and depth stratum, and were compared with a Kolmogorov-Smirnov test to check for significant differences between depth strata.

\section{RESULTS}

The catchability patterns of Nephrops norvegicus recorded through the temporal series of density estimates (Fig. 2a,b) showed marked and different rhythmic profiles both at 100 and $400 \mathrm{~m}$ in October and June. On the continental shelf at $100 \mathrm{~m}$ (Fig. 2a), 2 peaks of catch were observed per day, approximately coinciding with the sunset and the sunrise timing, in both seasons surveyed. Catches attained their lowest values during daylight hours. Animals were continuously captured at night time, although catches were consistently lower compared to those obtained at sunset and sunrise. On the slope at $400 \mathrm{~m}$ (Fig. 2b), catches revealed a single peak at around midday in both October and June surveys.

Light intensity values recorded on the shelf were from 6 - to 7 -fold larger than those recorded on the

Table 1. Numbers of trawl samples used for mean density estimation of Nephrops norvegicus at each $2 \mathrm{~h}$ time interval in the $24 \mathrm{~h}$ form-estimate analysis of time series of data recorded on the shelf $(100 \mathrm{~m})$ and slope $(400 \mathrm{~m})$ in October 1999 and June 2000. -: no samples collected at the corresponding time interval during the $4 \mathrm{~d}$ of fishing activity

\begin{tabular}{|lcccc|}
\hline \multirow{2}{*}{$\begin{array}{l}\text { Time interval } \\
\text { (h) }\end{array}$} & \multicolumn{5}{c}{ October } \\
& 100 & 400 & 100 & 400 \\
\hline $0-2$ & - & 1 & 3 & 2 \\
$2-4$ & 3 & 2 & 1 & 2 \\
$4-6$ & 2 & 2 & 4 & 4 \\
$6-8$ & 3 & 3 & 4 & 3 \\
$8-10$ & 4 & 5 & 4 & 3 \\
$10-12$ & 3 & 3 & - & 1 \\
$12-14$ & 1 & 3 & 3 & 3 \\
$14-16$ & 4 & - & 1 & 1 \\
$16-18$ & 3 & 4 & 3 & 4 \\
$18-20$ & 1 & 3 & 5 & 4 \\
$20-22$ & 4 & 4 & 4 & 4 \\
$22-0$ & 4 & 4 & - & - \\
\hline
\end{tabular}



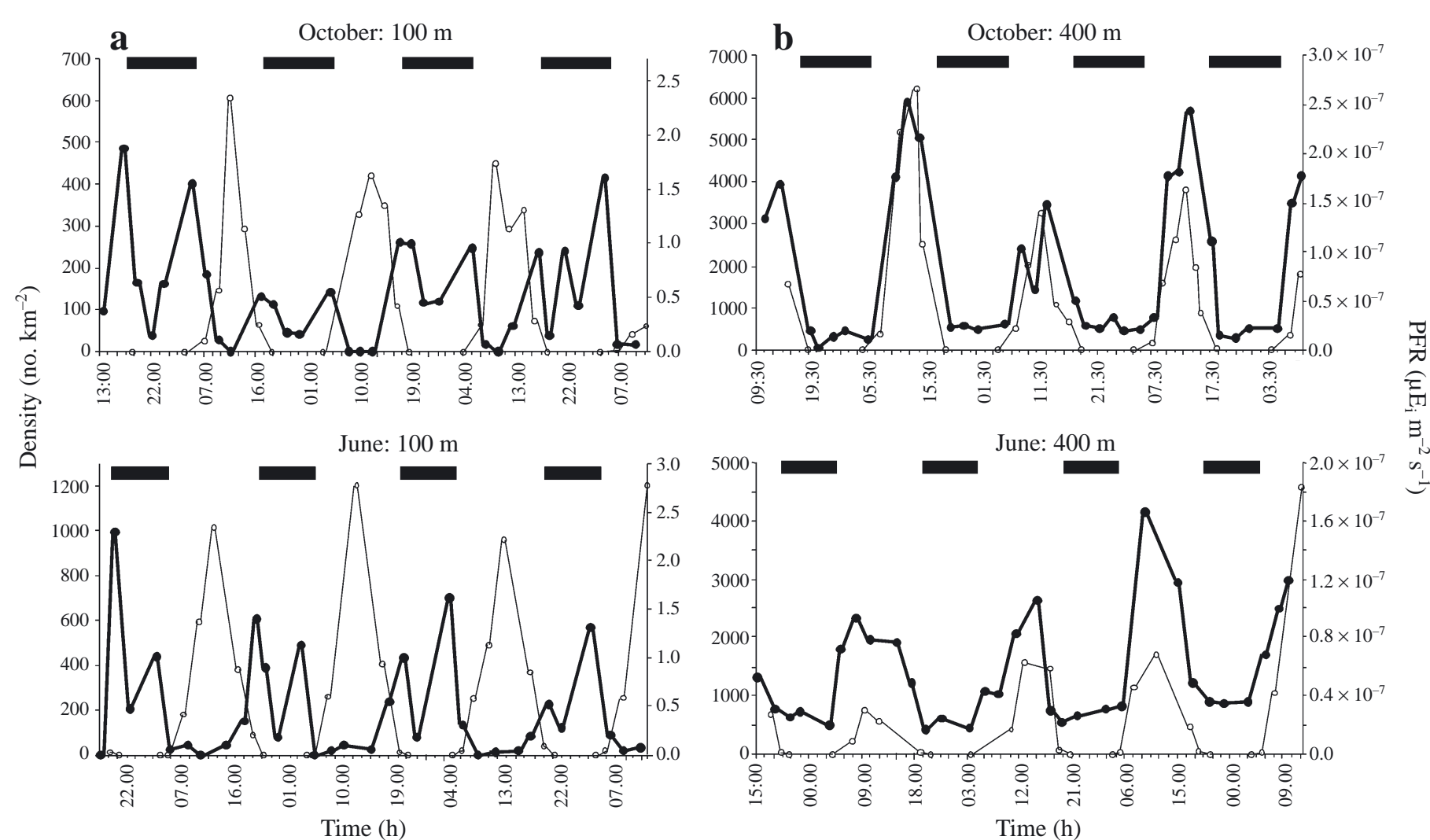

Fig. 2. Nephrops norvegicus. Density per haul (no. $\left.\mathrm{km}^{-2}\right)$ and light intensity measures as photon fluency rate $\left(\mathrm{PFR}_{\mathrm{r}} \mu \mathrm{E}_{\mathrm{i}} \mathrm{m}^{-2} \mathrm{~s}^{-1}\right)$, recorded during $4 \mathrm{~d}$ of fishing activity in October and June on (a) the continental shelf $(100 \mathrm{~m})$, (b) the continental slope (400 m).

(ש) Night period, ( $\bullet-)$ density of animals per haul, (-०) light intensity measures

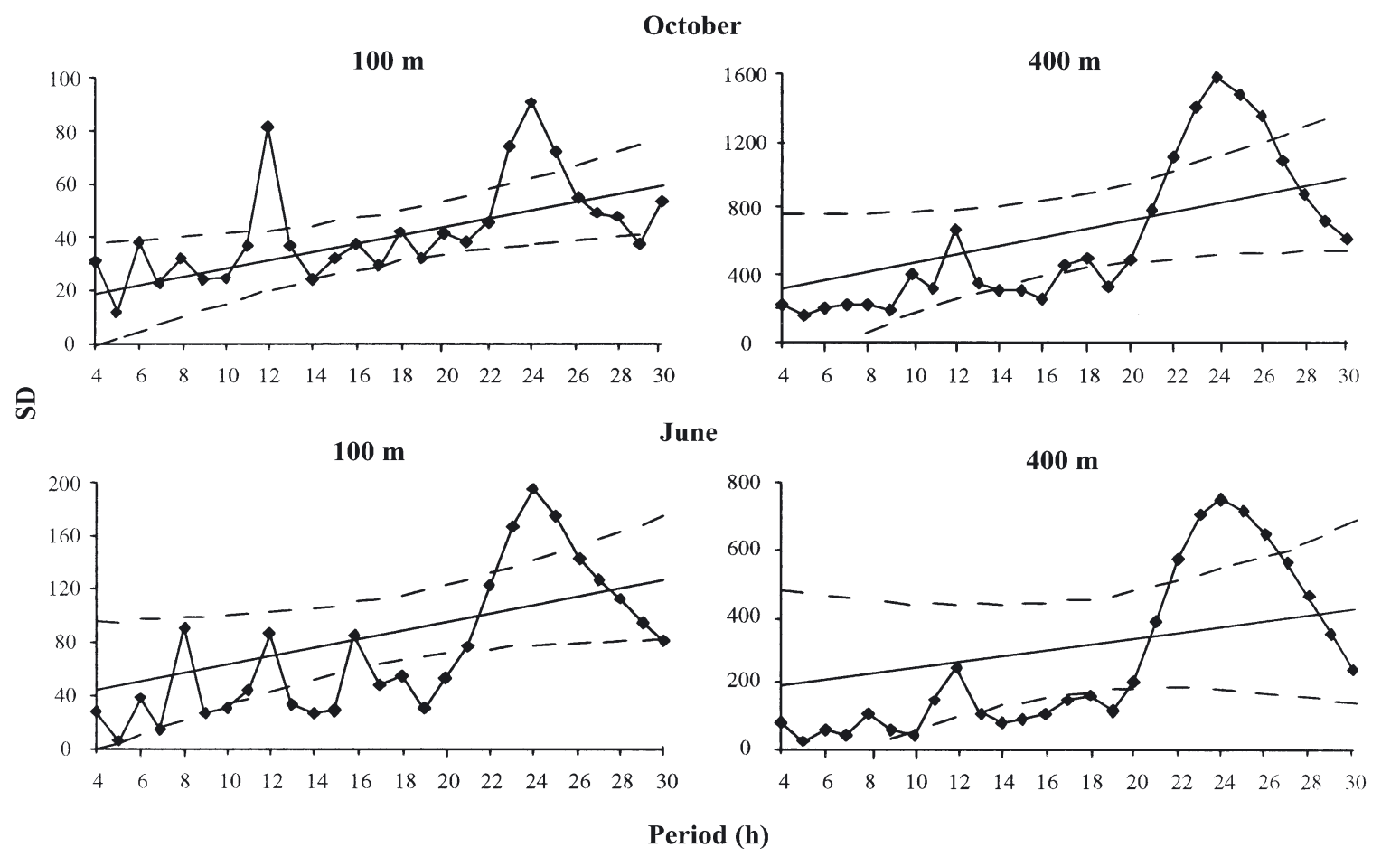

Fig. 3. Nephrops norvegicus. Periodogram analysis output of the time series of catch data at 100 and $400 \mathrm{~m}$ in October and June. SD: standard deviation as computed in Buys-Ballot Tables for each corresponding wavelength tested (see Williams \& Naylor 1978) 
slope (Fig. 2a,b). On the shelf, rhythms in catches and diel variation in light intensity were clearly not in phase. On the slope, a tight coupling in phases was found between catch and light level data. This comparison revealed that peaks of catch on the shelf occurred under light intensity values markedly different from those reported for the slope.

Periodogram analysis of the time series of catches showed a significant $24 \mathrm{~h}$ periodicity at $400 \mathrm{~m}$ in both October and June (Fig. 3). At 100 m, a significant $12 \mathrm{~h}$ periodicity was recorded in October, but a $24 \mathrm{~h}$ periodicity was detected in June.

Fig. 4 shows the $24 \mathrm{~h}$ form estimate analysis of the temporal series of catches and light intensity measures recorded at each depth and season. At $100 \mathrm{~m}$ in October, high catch levels were recorded throughout the night, peaking before sunrise and sunset. Sampled animals gradually fell to very low levels during the central hours of the day. In June at the same depth, 2 peaks were also detected at around sunrise and sunset. The overall pattern was similar to that recorded in October, but the distance between the peaks increased according to the photoperiod length variation. In particular, the sunrise peak did not vary its timing compared to the one of October, while the sunset peak delayed its appearance for a few hours. At $400 \mathrm{~m}$ in October, 1 single peak appeared during daylight hours. Low but constant levels of sampled organisms were reported during the night. At the same depth in June the peak of catches was recorded earlier than in October. Also, organisms did not disappear from night catches, maintaining a constant low presence.

The analysis of the differential emergence patterns between sexes showed an almost identical rhythmicity for males and females in October and June, on both shelf and slope environments (Fig. 5a,b), in agreement with overall patterns (Fig. 2a,b). On the shelf (Fig. 5a), numbers of sampled females exceeded slightly those of males in most samples taken in June but not in October, when numbers of males were generally higher.

Berried females on the slope also presented a marked rhythmicity of catches. A midday peak completely phased with recorded maxima in light intensity levels was reported, as for the overall population (Fig. 2b). This analysis was not performed for berried females on the shelf, due to the much lower occurrences at this depth.

The $24 \mathrm{~h}$ form-estimate analysis of density data within each of the 3 size classes considered $(\mathrm{CL}<$ $25 \mathrm{~mm} ; 25<\mathrm{CL}<35 \mathrm{~mm}$; CL $>35 \mathrm{~mm}$ ), revealed simi-
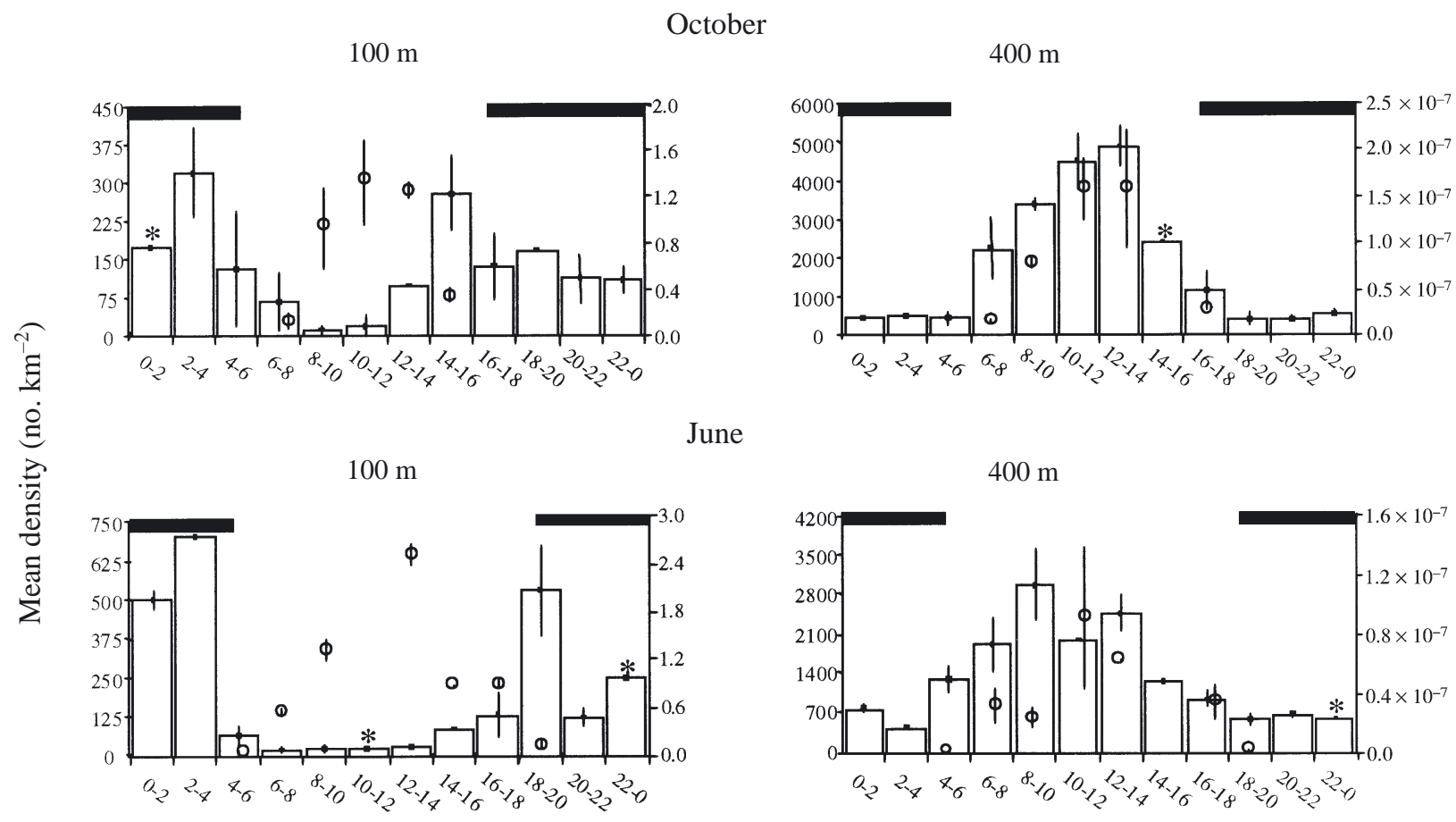

une

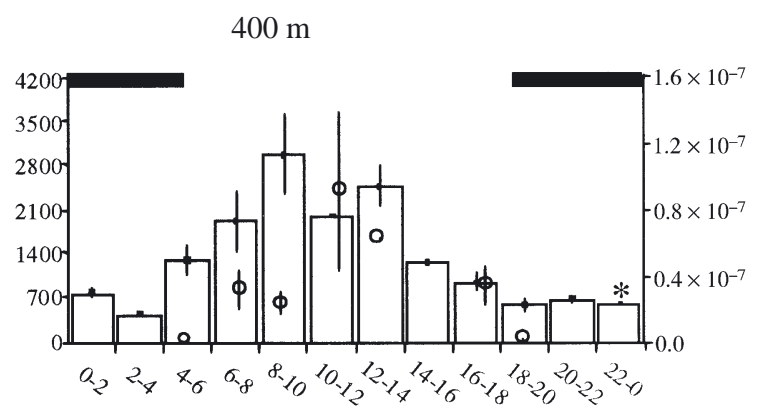

Time of day (h)

Fig. 4. Nephrops norvegicus. Periodicity of catches over $24 \mathrm{~h}$, and light intensity measures as photon fluency rate $\left(\mathrm{PFR}_{\mathrm{r}} \mu \mathrm{E}_{\mathrm{i}} \mathrm{m}^{-2}\right.$

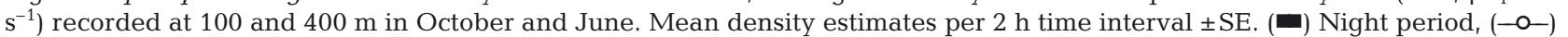
averaged light intensity measures, (*) missing data for this time interval, substituted by interpolation from adjacent time interval values 

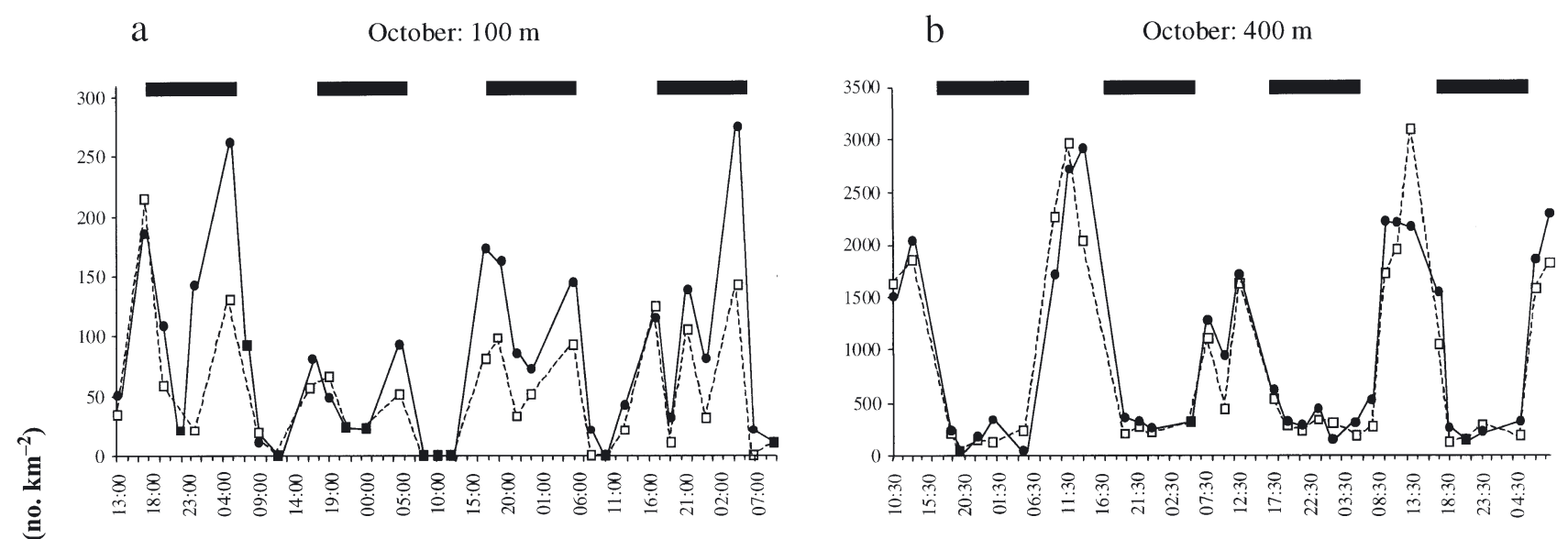

June: $100 \mathrm{~m}$

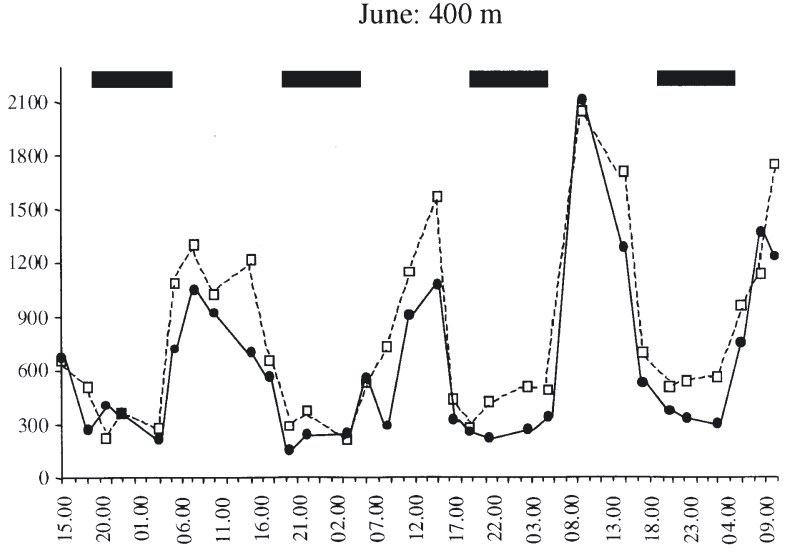

Time (h)

Time (h)

Fig. 5. Nephrops norvegicus. Density of $N$. norvegicus males and females (no. $\mathrm{km}^{-2}$ ) sampled during $4 \mathrm{~d}$ of fishing activity in October and June on (a) the continental shelf $(100 \mathrm{~m})$, and (b) the continental slope $(400 \mathrm{~m})$. ( $\square$ ) Night period, ( $\bullet-)$ density of males per haul, (--口--) density of females per haul

lar patterns in the rhythmic emergence behaviour both in October and June (Fig. 6a,b). At $100 \mathrm{~m}$ in both seasons considered, all size classes presented 2 peaks of catches, approximately phased with sunset and sunrise. At $400 \mathrm{~m}$ all size classes showed the same pattern, with a peak centred at midday both in October and June.

Size frequency distributions (Fig. 7) revealed significant differences between the 2 bathymetric stations sampled in every season for both sexes (Table 2). Animals from the continental shelf clearly reached larger sizes than those collected on the slope.

\section{DISCUSSION}

The present investigation showed that Nephrops norvegicus inhabiting the western Mediterranean continental shelf and slope show a marked rhythmicity in catches, as assessed by continuous cycles of trawl hauls both in October and June. On the continental shelf, the emergence pattern showed a marked bimodal profile with a crepuscular phase (peaks at sunset and sunrise), while on the slope it showed a marked unimodal profile phased at midday. Consequently, the emergence rhythmicity was modulated by depth-related factors. The western Mediterranean shelf animals behave as their Atlantic bathymetric equivalent in terms of periodicity and phase of their emergence from burrows. The slope population performs a diurnal emergence, therefore fully confirming the trend in peak-shift timing already suggested by Chapman et al. $(1972,1975)$ for depths greater than $200 \mathrm{~m}$.

Light intensity reaching the bottom modulates the rhythmic emergence behaviour in Nephrops norvegicus. As shown in this study, the time series of catches and bottom illumination fluctuate in phase on the slope, but not on the continental shelf. Chapman et al. $(1972,1975)$ already explained the coupling between 


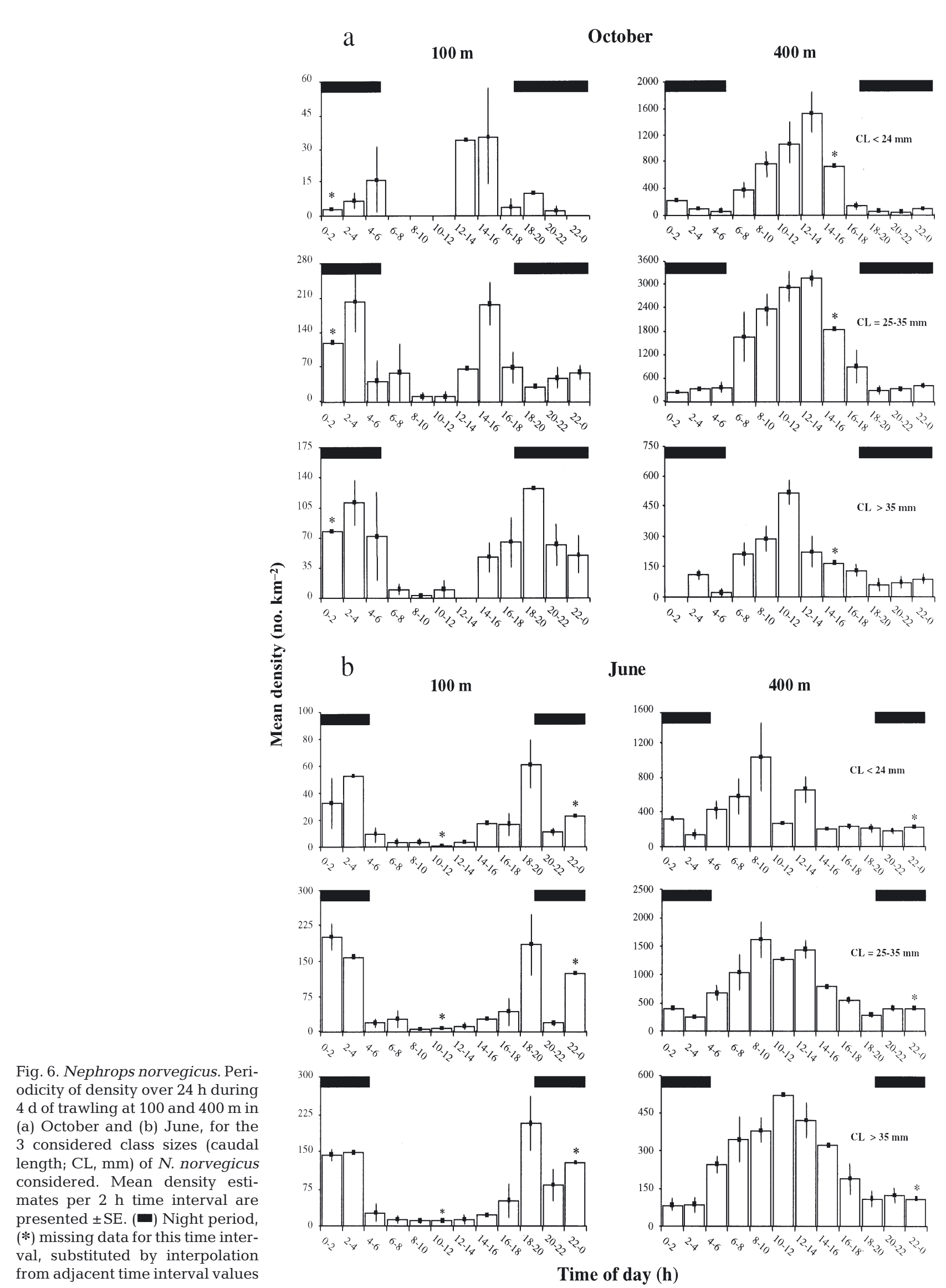

Fig. 6. Nephrops norvegicus. Peridicity of density over $24 \mathrm{~h}$ during consider, Mean density estimates per $2 \mathrm{~h}$ time interval are presented \pm SE. $(\mathbb{\square})$ Night period from adjacent time interval values

Time of day (h) 


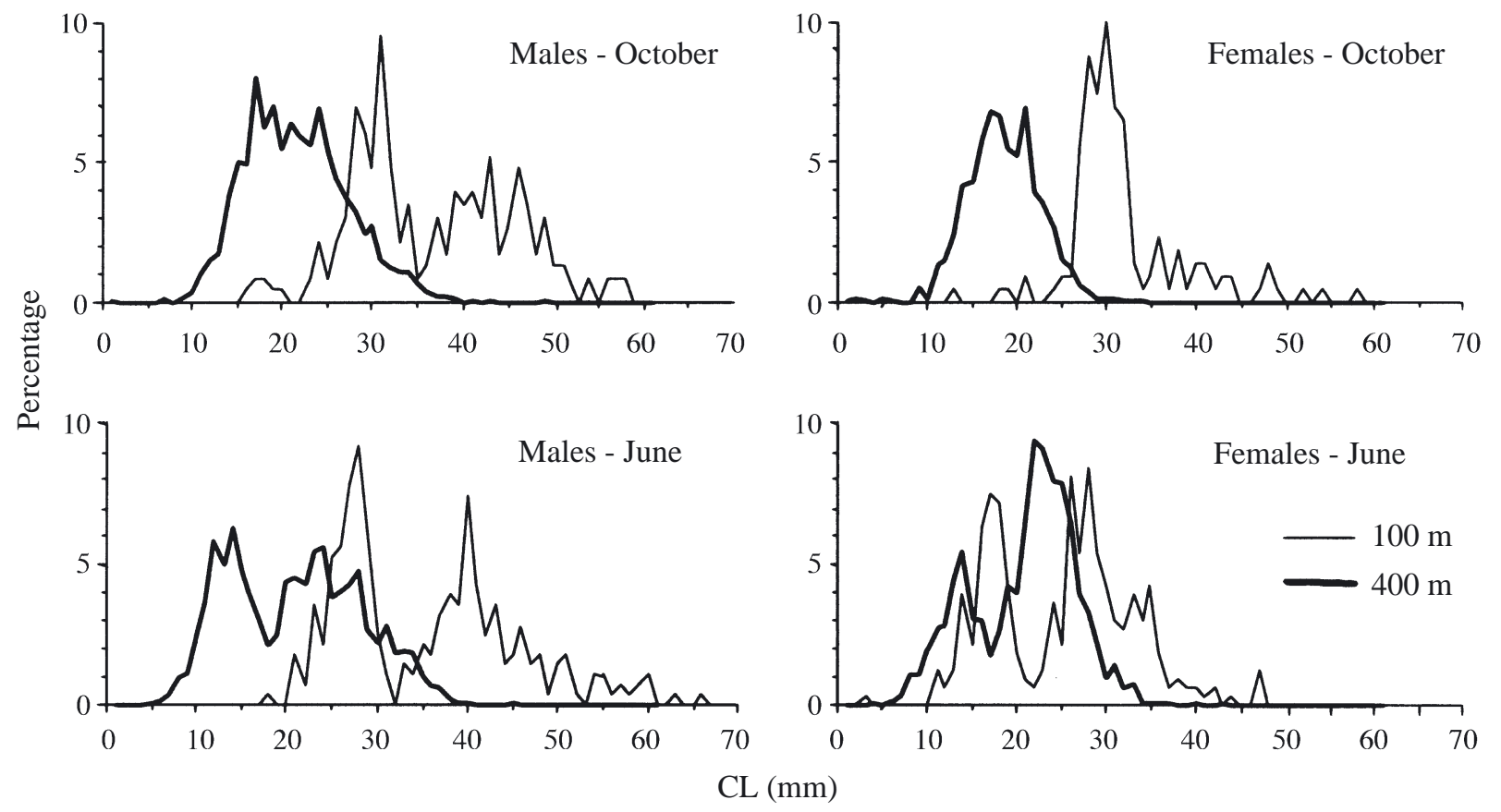

Fig. 7. Nephrops norvegicus. Comparison of size frequency distributions by depth for males and females collected on the shelf and slope during the October and June field surveys

emergence and the day-night cycle, by suggesting the existence of an optimum light intensity range at which this behaviour is strictly performed, and whose timing is depth-related. In the present study, different levels of light intensity were recorded on the shelf and slope. Thus, the phasing of emergence took place at very different levels of environmental illumination. The concept of an 'optimum light intensity' should therefore be reconsidered, since the light level triggering emergence cannot be the same, in terms of intensity (i.e. number of photons per unity of time) and spectral quality (i.e. wavelength range), in different hours of the day at different depths of the bathymetric range considered. As seen in this study, animals at both depths emerge from their burrows under different local stimulating light intensity. These results indicate the presence of a different and permanent state of

Table 2. Nephrops norvegicus. Results of the KolmogorovSmirnov test for size-frequency distribution comparisons between depth stations by sex. No. of individuals for each category is also presented

\begin{tabular}{|lccc|}
\hline & $\mathrm{N}(100 \mathrm{~m})$ & $\mathrm{N}(400 \mathrm{~m})$ & $\mathrm{p}$ \\
\hline Males October & 231 & 1168 & 0.01 \\
Females October & 144 & 1036 & 0.01 \\
Males June & 283 & 1202 & 0.05 \\
Females June & 333 & 1534 & 0.01 \\
\hline
\end{tabular}

adaptation of the eye of $N$. norvegicus on shelf and slope bottoms. This is in agreement with findings reported by Gaten et al. (1990), suggesting that animals of different bathymetric populations experience different retina damage when captured. In this sense, eye sensitivity results from an acclimation to different local photic conditions. As reported by Loew (1974), $N$. norvegicus visual pigments present a maximum absorption of light at a wavelength around $480 \mathrm{~nm}$. Light of this wavelength is present down to almost $800 \mathrm{~m}$, depending on the transparency of the upper layers (Frank \& Widder 2002). Therefore, data from the present study suggest that fluctuations of such highfrequency light intensity could invariantly affect emergence behaviour of animals of all depths, including those dwelling on the slope. It is reasonable that the emergence behaviour of $N$. norvegicus could be regulated by an optimum monochromatic light intensity interval, made by photons of this particular wavelength (around $480 \mathrm{~nm}$ ).

The Nephrops norvegicus emergence rhythmicity was also clearly modulated by photoperiod length duration. Two distinct peaks of catches were detected in the shelf population, both in October and June. However, these were recognised as significantly different in October near the equinox, when day and night had approximate equal duration, but not in the solstice, when night duration was much shorter. The 2 peaks in June were much closer in time than in Octo- 
ber. Both were therefore confounded into a single peak of $24 \mathrm{~h}$ by periodogram analysis, given the restriction imposed by the sampling periodicity that took place approximately every 2 to $3 \mathrm{~h}$. In particular, the corresponding $24 \mathrm{~h}$ form estimates reveal that the sunset peak was closer to the onset of the night in June than in October. In fact, summer day-night transitions take place more abruptly than in autumn, due to the differential height of the sun at the horizon in both seasons. The sunrise peak of catch maintained a fixed time position over both seasons, while the sunset peak displaced its timing of occurrence later from October to June. Therefore, the timing of emergence of $N$. norvegicus over different seasons may be modulated by diel light intensity transitions occurring at sunset (Hammond \& Naylor 1977), differently from other crustacean species mainly responding to sunrise effects (e.g. Williams 1980a,b).

The occurrence of diel differences in catchability coupled to light intensity variations is a common feature within the Nephropidae, as shown by the catch patterns of Metanephrops thomsoni in the East China Sea (Matsuoka et al. 1992) and Metanephrops australiensis off NW Australia (Ward \& Davis 1987). M. thomsoni on the continental shelf (around $100 \mathrm{~m}$ ) emerged at night-time, while $M$. australiensis at depths of $430 \mathrm{~m}$ was clearly crepuscular with peaks of catches at sunset and sunrise. The pattern shown by M. australiensis is similar to that shown by Nephrops norvegicus in deep-shelf Atlantic and western Mediterranean waters, but differs from that found in the present study at a corresponding depth (i.e. $400 \mathrm{~m}$ ). This difference can be attributed to the exceptionally clear and transmissive character of Australian tropical waters (Ward \& Davis 1987).

Ecological factors, other than direct light intensity, could modulate the emergence behaviour of Nephrops norvegicus and other co-occurring benthic species. In the Mediterranean, the rhythmic diel pattern of occurrence of benthopelagic species near the bottom could also play an important role in providing timing cues to bottom-dwelling organisms, especially so in the deeper areas where light intensity levels are extremely low. This dynamic effect was already proposed by Naylor \& Atkinson (1976) and Al-Adhub \& Naylor (1977) concerning the emergence of Atlantic N. norvegicus as a response to the diel presence-absence of the epibenthic-pelagic prey shrimp Dichelopandalus bonnieri, as well as by Lagardère (1977), Cartes (1993) and Cartes et al. (1993), among other authors, concerning other continental slope communities. In the Mediterranean, day-night changes in the feeding activity and food composition of several slope organisms, including $N$. norvegicus, suggest a link between behavioural activity and nictemeral migrations of prey organisms, due to the occurrence of vertically migrating bathypelagic species, such as Pasiphaea sivado, $P$. multidentata, Sergestes arcticus or Meganyctiphanes norvegica (Cartes 1993, Cartes et al. 1993, Cristo 1998, Cristo \& Cartes 1998).

Present results show a similar emergence rhythmicity for both males and females, as already reported for Nephrops norvegicus by Atkinson \& Naylor (1976). Sex-related differences in emergence rhythmicity were often invoked in particular periods of the year to account for the differential catchability of berried females both in the Atlantic (Poulsen 1946, Thomas \& Figueiredo 1964, Jensen 1965, Rice \& Chapman 1971, Farmer 1975) and in the Mediterranean Sea (Karlovac 1953, Sardà 1995, Relini et al. 1998). The proportion of females in commercial catches decreases markedly during the egg-carrying season, providing indirect evidence of their increased concealment into burrows at that time (Chapman \& Rice 1971, Rice \& Chapman 1971). Despite this indirect evidence, present results show that berried females may perform rhythmic emergence phased to light intensity cycles like the all other individuals of the population.

A shift in emergence behaviour timing linked to the size of the animals was also proposed in the literature. Andersen (1962) and Chapman \& Howard (1979) reported that day catches obtained larger individuals than night ones. On the contrary, Froglia (1972) and Farmer (1974a) reported the opposite situation. Redant \& De Clerk (1984) reported in Atlantic waters that catches differed in their size composition depending on the time of day, and attributed this to a possible size-related differential timing of emergence. However, no evidence was seen in the present study concerning any differential catchability as a function of the size of the animals. For any depth and season considered, present results indicate a clear and similar rhythmic emergence pattern for all size classes, including juveniles. According to Farmer (1974a,b) and Chapman \& Howard (1979), large individuals are less inclined to remain in burrows, and their concealment apparently decreases with increasing size (Chapman \& Rice 1971). Following these authors, the large sized individuals seem to spend most of their time on the bottom surface, where they are less vulnerable to a predation threat due to their dimensions. In the present study, individuals over 35 $\mathrm{mm}$ CL also presented a marked rhythmic catchability pattern, suggesting a strong modulation of their emergence behaviour, similar to their smaller conspecifics.

Present results provided an insight into the differential behaviour of western Mediterranean populations of Nephrops norvegicus inhabiting the continental shelf and those in deeper waters on the slope. The dif- 
ferences observed in catchability patterns in the 2 environments have also important implications concerning the management of the fishery, since night trawling is prohibited in the study area. This timetrawling schedule protects the shelf population, where densities are lower, but not the slope population, where densities are the highest. In fact, as revealed in the present investigation, animals on the shelf reach significantly larger sizes than those on the slope, probably due to the lower fishing pressure on the shelf population due to its crepuscular emergence behaviour. Possible changes in policy concerning the timing of the allowed trawling activity (e.g. by allowing night trawling) may negatively affect the shelf population, which is presently less exploited due to its emergence behaviour characteristics and lower densities. This population may consequently act as a source reserve for the more exploited, deeper populations in the region.

Acknowledgements. The present work was developed in the context of a national research project funded by the Spanish Ministry of Research (CICYT) (NERIT: MAR98-0935). The authors want also to thank the crew of RV 'García del Cid' (CSIC) for their support during sampling. A special thanks also goes to J. A. García, B. Molí and A. Castellón for their valuable technical help during sampling operations.

\section{LITERATURE CITED}

Aagaard A, Warman GC, Depledge MH, Naylor E (1995) Dissociation of the heart rate and locomotor activity during the expression of rhythmic behaviour in the shore crab Carcinus maenas. Mar Freshw Behav Physiol 26 (1):1-10

Abelló P, Valladares FJ, Castellón A (1988) Analysis of the structure of decapod crustacean assemblages off the Catalan coast (North-West Mediterranean). Mar Biol 98:39-49

Abelló P, Abella A, Adamidou A, Jukic-Peladic S, Maiorano P, Spedicato MT (2002a) Geographical patterns in abundance and population structure of Nephrops norvegicus and Parapenaeus longirostris (Crustacea: Decapoda) along the European Mediterranean coasts. Sci Mar 66(Suppl 2):125-141

Abelló P, Carbonell A, Torres P (2002b) Biogeography of epibenthic crustaceans on the shelf and upper slope off the Iberian Peninsula Mediterranean coasts: implications for the establishment of natural management areas. Sci Mar 66(Suppl 2):183-198

Al-Adhub AHY, Naylor E (1977) Daily variation in Dichelopandalus bonnieri (Caullery) as a component of the epibenthos. In: Keegan BF, O'Ceidigh P, Boaden PJS (eds) Biology of benthic organisms. Pergamon Press, New York, p 1-6

Andersen FS (1962) The Norway lobster in the Faroe waters. Medd Dan Fisk Havunders NY Ser 3(9):265-326

Atkinson RJA, Naylor E (1976) An endogenous activity rhythm and the rhythmicity of catches of Nephrops norvegicus (L). J Exp Mar Biol Ecol 25:95-108

Cartes JE (1993) Day-night feeding by decapods crustaceans in a deep-water bottom community in the Western Mediterranean. J Mar Biol Assoc UK 73:795-811
Cartes JE, Sardà F (1993) Zonation of deep-sea decapod fauna in the Catalan Sea (Western Mediterranean). Mar Ecol Prog Ser 94:27-34

Cartes JE, Sardà F, Company JB, Lleonart J (1993) Day-night migrations by deep-sea decapod crustaceans in experimental samplings in the Western Mediterranean sea. J Exp Biol Ecol 171:63-73

Chapman CJ, Howard FG (1979) Field observations on the emergence rhythm of the Norway lobster Nephrops norvegicus using different methods. Mar Biol 51:157-165

Chapman CJ, Rice AL (1971) Some direct observations on the ecology and behaviour of the Norway lobster Nephrops norvegicus. Mar Biol 10:321-329

Chapman CJ, Pristley R, Robertson H (1972) Observations on the diurnal activity of the Norway lobster Nephrops norvegicus (L). ICES CM/K:20

Chapman CJ, Johnstone ADF, Rice AL (1975) The behaviour and ecology of the Norway lobster Nephrops norvegicus (L). In: Persoone G, Jaspers E (eds) Proc Eur Mar Biol Symp Universa Press, Wetteren, p 59-74

Cristo M (1998) Feeding ecology Nephrops norvegicus (Decapoda Nephropidae). J Nat His 32:1493-1498

Cristo M, Cartes JE (1998) A comparative field study of feeding ecology of Nephrops norvegicus (L) (Decapoda: Nephropidae) in the bathyal Mediterranean and adjacent Atlantic. Sci Mar 62(Suppl 1):81-90

Farmer ASD (1974a) Field assessments of diurnal activity in Irish Sea populations of the Norway Lobster Nephrops norvegicus (L) (Decapoda: Nephropidae). Estuar Coast Mar Sci 2:37-47

Farmer ASD (1974b) Burrowing behaviour of the Norway lobster Nephrops norvegicus (L) (Decapoda: Nephropidae). Estuar Coast Mar Sci 2:49-58

Farmer ADS (1975) Synopsis of biological data on Norway lobster Nephrops norvegicus (Linneo 1758). FAO Fisheries Synopsis 112:1-97

Frank TM, Widder EA (2002) Effects of a decrease in downwelling irradiance on the daytime vertical distribution patterns of zooplankton and micronekton. Mar Biol 140: $1181-1193$

Froglia C (1972) Osservazioni sulle variazioni di cattura dello scampo Nephrops norvegicus (L) in riferimento all'etologia ed alla biologia della specie. Quad Lab Tecnol Pesc 1(4):83-99

Gaten E, Shelton PMJ, Chapman CJ, Shaks AM (1990) Depth related variation in the structure and functioning of the compound eye of the Norway lobster Nephrops norvegicus. J Mar Biol Assoc UK 70:343-355

Hammond RD, Naylor E (1977) Effects of dusk and down on locomotor activity rhythms in the Norway lobster Nephrops norvegicus. Mar Biol 39:253-260

Jensen AJC (1965) Continued investigation on Nephrops in the Skagerrak, Kattegat and North Sea. ICES CM/119:4

Jukic S (1971) Studies on the population and the catchability of Norway lobster in the Central Adriatic. Stud Rev Gen Fish Counc Mediterr 48:27-53

Karlovac O (1953) An ecological study of Nephrops norvegicus (L) of the high Adriatic. Izv Inst Oceanogr Ribar 5(2C): $1-51$

Lagardère JP (1977) Recherches sur la distribution verticale et sur l'alimentation des crustacés décapodes benthiques de la pente continentale du Golfe de Gascogne: analyse des groupements carcinologiques. Bull Cent Etud Rech Sci Biarritz 11:367-440

Loew ER (1974) Light-induced rhabdometric degeneration in the Norway lobster Nephrops norvegicus (L). ICES $\mathrm{CM} / \mathrm{K}: 29$ 
Main J, Sangster GI (1985) The behaviour of the Norway lobster Nephrops norvegicus (L) during trawling. Scott Fish Res Rep 34:1-23

Matsuoka M, Tokimura M, Fujita H, Kitajima T (1992) A consideration on differences of catch compositions between daytime and night time bottom trawl samplings in the East China Sea. Bull Seikai Natl Fish Res Inst 70:1-9

Maynou FX, Sardà F (1997) Nephrops norvegicus population and morphometrical characteristic in relation to substrate heterogeneity. Fish Res 30:139-149

Maynou FX, Sardà F, Conan GY (1998) Assessment of the spatial structure and biomass evaluation of Nephrops norvegicus (L.) populations in the northwestern Mediterranean by geostatistic. ICES J Mar Sci 55:102-120

Moller TH, Naylor E (1980) Environmental influence on locomotor activity in Nephrops norvegicus (Crustacea: Decapoda). J Mar Biol Assoc UK 60:103-113

Naylor E, Atkinson RJA (1976) Rhythmic behaviour of Nephrops and some other marine crustaceans. In: SpencerDavis P (ed) Perspectives in experimental biology. Pergamon Press, Oxford, p 135-143

Newland PL, Neil DM, Chapman CJ (1992) Escape swimming in the Norway lobster. J Crustac Biol 12(3):342-353

Oakley SG (1979) Diurnal and seasonal changes in the timing of peak catches of Nephrops norvegicus reflecting changes in behaviour. In: Naylor E, Hartnoll RG (eds) Cyclical phenomena in marine plants and animals. Pergamon Press, Oxford, p 367-373

O'Riordan T (1964) Nephrops norvegicus the Dublin bay prawn in Irish waters. Sci Proc R Dubl Soc (B) 1:131-157

Poulsen EM (1946) Investigation on the Danish fishery for and the biology of the Norway lobster and the deep-sea prawn. Rep Dan Biol Stn 48:27-49

Redant F, De Clerck R (1984) Diurnal variations in CPUE and length composition of the catches in a Nephrops directed fishery in the Central North Sea. ICES CM/K:3

Relini G, Zamboni A, Masse D, Fiorentino E (1998) Behaviour of the exploited demersal resources of the Ligurian Sea

Editorial responsibility: Otto Kinne (Editor), Oldendorf/Luhe, Germany through twelve years series of biomass indices. Rapp Comm Int Mer Médit 35:480-481

Rice AL, Chapman CJ (1971) Observations on the burrows and burrowing behaviour oftwo mud-dwelling decapod crustaceans Nephrops norvegicus and Goneplax rhomboides. Mar Biol 10:330-342

Sardà F (1991) Reproduction and moult synchronism in Nephrops norvegicus (L) (Decapoda Nephropidae) in the Western Mediterranean: is spawning annual or biennial? Crustaceana 60(2):186-199

Sardà F (1995) A review (1967-1990) of some aspects of the life history of Nephrops norvegicus. ICES Mar Sci Symp 199:78-88

Sardà F, Cartes JE, Company JB, Antoni A (1998) A modified commercial trawl used to sample deep-sea megabenthos. Fish Sci 64(3):492-493

Simpson AC (1965) Variations in the catches of Nephrops norvegicus at a different time of day and night. Rapp P-V Réun 156(35):186-189

Sparre P, Ursin E, Vemena SC (1989) Introduction to tropical fish stock assessment. Part 1. Manual FAO fisheries technical paper (306/1). FAO, Rome

Thomas HJ, Figueiredo MJ (1964) Seasonal variations in the stock composition of the Norway lobster (Nephrops norvegicus L.) around Scotland. ICES CM/131:13

Ward TJ, Davis TLO (1987) Diel periodicity of Metanephrops australiensis and other deep-water crustaceans of northwest Australia. Fish Res 5:91-97

Williams JA (1980a) The light-response rhythm and seasonal entrainment of the endogenous circadian locomotor rhythm of Talitrus saltator (Crustacea: Amphipoda). J Mar Biol Assoc UK 60:773-785

Williams JA (1980b) The effect of dusk and dawn on the locomotor activity rhythm of Talitrus saltator (Montagu) (Crustacea: Amphipoda). J Exp Mar Biol Ecol 42:285-297

Williams JA, Naylor E (1978) A procedure for the assessment of significance of rhythmicity in time-series of data. Int $\mathrm{J}$ Chronobiol 5:435-444

Submitted: January 30, 2003; Accepted: May 6, 2003

Proofs received from author(s): July 22, 2003 